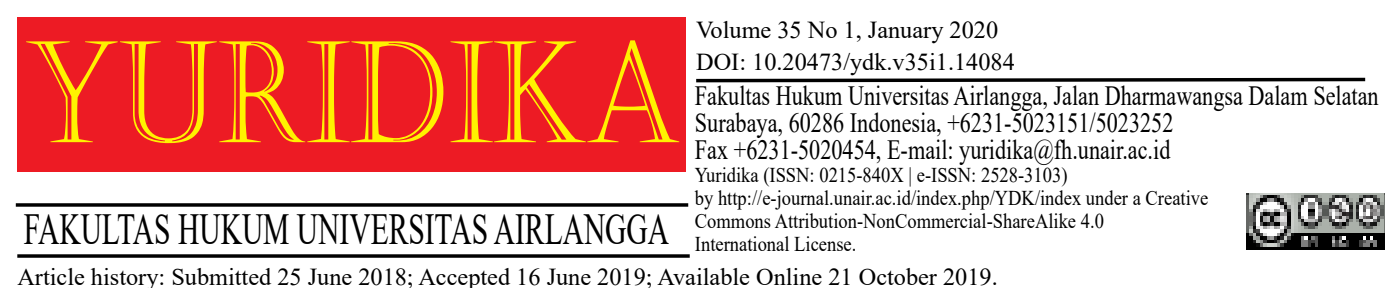

\title{
Sharia Principles on Information Technology-Based Financing Services
}

\author{
Trisadini Prasastinah Usanti, Prawitra Thalib and Nur Utari Setiawati \\ trisadini@fh.unair.ac.id \\ Universitas Airlangga
}

\begin{abstract}
The Financial Services Authority only regulates information technology-based money lending and borrowing services that have not yet regulated sharia-based information technology financing services (fintech Syariah). This is evidenced by the provision of loan interest rates in the Financial Services Authority Regulation. This is contrary to sharia principles. The existence of Fintech Syariah is only based on DSN-MUI Fatwa Number 117/DSN-MUI/II/2018 which expressly states that information technology-based financing services are permitted with conditions that must be by sharia principles so that they cannot promise usury, gharar, maysir, tadlis, and dharar. Contracts that frame the legal relationship between the organizer, the financing provider and the recipient of financing, among others, the contract of wakalah bil ujrah, mudharabah, musyarakah, ijarah, and murabahah.
\end{abstract}

Keywords: Fintech; Shariah; Contract.

\section{Introduction}

Borrowing from each other is a legal act that is commonly practiced by legal subjects when it requires funds. One financial institution that conducts lending and borrowing activities is a banking institution, which is known as credit while in Islamic banking, it is known as Al-Qardh financing. Credit Definition according to Act Number 7 of 1992 concerning Banking as amended by Act Number 10 of 1998 (Banking Law) is the provision of money or bills that can be equated with it, based on an agreement or loan agreement between the bank and other parties that require the borrowing party to repay the debt after a certain period of time with interest. While Al-Qardh according to DSN Fatwa Number 19/DSN-MUI/IV/ 2001 is a loan given to customers (muqtaridh) who need and are obliged to return the principal amount received at the time agreed. Customers can voluntarily provide donations 
(donations) to Islamic Financial Institutions (LKS) as long as they agreed upon in the contract. According to the explanation in Article 19 letter e of Law Number 21 the Year 2008 concerning Sharia Banking (Sharia Banking Law) Qardh Agreement is a loan agreement to the Customer provided that the Customer is obliged to return the funds received at the agreed time.

Besides banking institutions, lending and borrowing activities are also carried out by non-bank financial institutions, namely financing institutions such as venture capital companies that carry out financing/equity participation in companies that receive financial assistance or mortgage companies that channel loans to their customers. Lending and borrowing activities are activities that must be carried out by banks as an embodiment of the intermediation function. Loans channeled by banks must be based on the precautionary principle, namely in the form of signs that must be obeyed by the bank so that not all applications submitted by prospective customers are approved if not bankable, that is, they do not meet bank requirements. It is often experienced by micro, small and medium enterprises (in the future referred to as MSMEs), which are just starting a business often rejected by banks because their business is not bankable and not feasible. It is not easy for MSMEs and startup businesses to have access to bank loans as a means of financing because banking regulations have special terms and conditions that apply even though this business needs financial support from investors.

So in 2016, the Financial Services Authority (OJK) launched the Financial Services Authority Regulation Number 77 /POJK.01/2016 Concerning Information Technology-Based Lending and Borrowing Services (POJK 77/2016). Information Technology-Based Lending and Borrowing Service is the implementation of financial services to bring lenders and loan recipients together to enter into a loan and loan agreement in rupiah currency directly through an electronic system using the internet network. It even mentioned that Information Technology-Based Money Lending and Borrowing Services was very helpful in increasing people's access to financial services products online both with various parties without the need to know each other. 
Until May 2019, Fintech Lending Company licensed and registered with the Financial Services Authority (OJK) as many as 113 whose types of business consisted of conventional operators and organizers based on sharia principles ${ }^{1}$ There are five licensed Fintech operators, namely Danamas, Investree, Amartha, Dompet Kilat and Kimo, the rest which is registered. While fintech operators based purely on sharia principles are: Ammana (PT. Ammana Fintek Syariah), Danasyariah (PT. Syariah Syariah Indonesia), Danakoo (PT. Danakoo Mitra Artha), Alamisharia (PT. Al Famiq Syariah) and Duha Syariah (PT Duha Mandani Syariah), ${ }^{2}$ while investree (PT. Investree Radhika Jaya) has a business type based on sharia besides conventional. Based on the description above, what is being analyzed in this article is about information technology-based financing services based on sharia principles by taking case studies on the implementation of Islamic fintech, namely Ammana, Danasyariah, and Duha Syariah.

\section{Contract in Information Technology Based Financing Services Based on}

\section{Sharia Principles}

Information Technology Lending and Borrowing Service Activities are carried out by Information Technology-Based Lending and Borrowing Service Providers, in the future referred to as Providers. ${ }^{3}$ The Provider provides, manages, and operates the Information Technology Money Lending Service from the lender to the recipient of the loan whose source of funds comes from the lender. There are three parties in the service of borrowing and borrowing money based on information technology, that is: ${ }^{4}$

\footnotetext{
1 Otoritas Jasa Keuangan, 'Penyelenggara Fintech Terdaftar Dan Berizin Di OJK per 31 Mei 2019' (Otoritas Jasa Keuangan, 2019) <https://ojk.go.id/id/berita-dan-kegiatan/publikasi/Pages/Penyelenggara-Fintech-Terdaftar-dan-Berizin-di-OJK-per-31-Mei-2019.aspx> accessed 27 May 2019.

2 ibid.

3 Indonesian Legal Entities can be in the form of Limited Liability Companies or Cooperatives

4 Trisadini Prasastinah Usanti and Fiska Silvia, 'Legal Protection of The Contracting Parties in The to Peer Lending Based on Financial Technology (P2P Lending Fintech) in Indonesia' (2018) 131 Advance in Social Science, Education and Humanities Research (SSEHR).[285].
} 
1. The Organizer;

2. Lenders;

3. Loan recipients.

The three parties framed in two agreements, namely agreements between the organizers and lenders and agreements between lenders and loan recipients. The organizer as a party that connects the lender and the recipient of the loan so that the organizer gets a commission as referred to in Article 19 paragraph (2) POJK 77/2016.

In POJK 77/2016, it does not regulate information technology-based services based on sharia principles; it only regulates services based on conventional information technology, which can be proven that: ${ }^{5}$

1. Regulations concerning legal relations between the organizer and the lender and between the lender and the recipient of the loan as outlined in an electronic document in which there is an agreement on the interest rate of the loan and the provisions regarding fines (if any). Determination of loan interest rates is not a profit justified by sharia principles. Interest is usury, which prohibited in all transactions. Referring to the opinion of Khotibul Umam, in his article that: to date, there are two views related to bank interest and usury. Namely the view that equates bank interest with usury regardless of the size of interest collected, and the view that distinguishes bank interest from usury, which has implications for bank interest in transactions as long as the bank is following the interest rate policy set by the government. Indonesia through the fatwa Number 1 of 2004 issued by the Indonesian Ulema Council included in the group that equates bank interest with usury.

2. There is no regulation regarding the Sharia Supervisory Board (DPS), if the organizer is in the form of a legal entity limited liability company, or cooperative that runs its activities based on sharia principles, ${ }^{6}$ the existence of DPS is required

\footnotetext{
5 Khotibul Umam, 'Pelarangan Riba Dan Penerapan Prinsip Syariah Dalam Sistem Hukum Perbankan Di Indonesia' (2017) 27 Mimbar Hukum.

${ }^{6}$ Prawitra Thalib, 'Application of Qowaid Fiqhiyyah in Islamic Contemporary Law' (2016) 31 Yuridika.[109].
} 
as stipulated in Article 109 of Law Number 40 of 2007 concerning Limited Liability Companies. Whereas one of the characteristics of Islamic Financial Institutions (LKS), namely the existence of DPS which tasked with providing advice and advice to directors and overseeing LKS activities following Sharia Principles such as the existence of DPS on Islamic banks, Islamic finance companies, and sharia mortgage companies.

3. It is related to the title of POJK 77/2016 about information technology, lending, and borrowing services. The meaning of borrowing and borrowing as mentioned in the description above is an agreement from Al Qardh while contracts that frame the legal relationship between the parties to Sharia fintech are unlimited in the Al Qardh contract, but it is possible to have a wakalah contract, mudaraba contract, musyarakah contract, and murabahah contract. When the OJK issues a Financial Services Authority Regulation specifically regulating Islamic fintech, it is not appropriate to use the word "borrow and borrow" but to use the word financing because it means the provision of funds or bills equivalent to that framed by a mudharabah, musyarakah, ijarah, ijarah muntahiyah bittamlik agreement, murabaha, salam, istishna, and qardh.

When comparing with the Financial Services Authority Regulation Number 31/POJK.05/2016 (POJK 31/2016) Which regulates the Mortgage Business. Then the POJK 31/2016 provides an opportunity for multi-finance companies to carry out their activities based on sharia principles. It is explicit there are norms about the definition of sharia principles, the obligation of the existence of DPS when the mortgage company submits a business license to the OJK, the obligation to include the word pawn followed by sharia for the mortgage company that runs all business activities based on sharia principles. So it is unfortunate if the FSA until now does not make its regulations for fintech based on sharia principles.

Therefore, based on the fatwa application letter from PT. Investree Radhika Jaya and PT. Ammana Fintek Syariah, the National Sharia Council-Indonesian Ulema Council issued DSN-MUI Fatwa Number 117/DSN-MUI/II/2018 concerning Information Technology-Based Financing Services Based on Sharia Principles 
(DSN-MUI Fatwa No.117). This fatwa was issued because it was needed to explain the provisions and legal restrictions related to fintech based on sharia principles. In this DSN-MUI Fatwa No.117, it stated explicitly that information technologybased financing services are permitted on conditions following sharia principles so that they cannot be promised riba, ${ }^{7}$ gharar, ${ }^{8}$ maysir ${ }^{9}$ tadlis $^{10}$ dan dharar. ${ }^{11}$

According to A. Shomad that Sharia, Shari'at, this term means "way" or path to the water source ", meaning the road that is clay: the road that the waterfall passes: the road to the water source or the place where people drink, especially on the road the path to the water trough is fixed and given a clear sign of the eye, so that means the road is clearly visible or the road that must be followed. ${ }^{12}$ Likewise stated by Prawitra Thalib in his article that:" "Sharia revealed for guidelines in touch with God, each other, environment and life every day. Islamic law has characteristics that distinguish it from other legal systems in the world ". Sharia, according to the banking dictionary, means the way of Allah as shown in the Qur'an and the Sunnah of the Prophet Muhammad. ${ }^{14}$ This term used for those related to Islamic law. ${ }^{15}$

In the DSN-MUI Fatwa No.117 states that the Agreement that frames the legal relations of the parties in sharia fintech includes al-bai, ijarah, mudharabah, musyarakah contract, ujrah, and Qardh bill. Organizers are allowed to charge fees

\footnotetext{
7 Based on DSN-MUI Fatwa No.117, what is meant by usury is an addition that is given in the exchange of goods usury (usury fadl) or an additional agreed upon on the principal debt in return for the suspension of absolute payment (usury nasi'ah)

8 Based on DSN-MUI Fatwa No.117, what is meant by Gharar is uncertainty in a contract, both regarding the quality or quantity of the object of the contract and regarding its award.

9 Based on DSN-MUI Fatwa No.117, what is meant by Maysir is any contract made with unclear objectives, and inaccurate calculations, speculations, or profitability

${ }^{10}$ Based on DSN-MUI Fatwa No.117, what is meant by Tadlis is the act of hiding the disability of the contract object which is carried out by the seller to trick the buyer as if the object of the contract is not flawed.

11 Based on DSN-MUI Fatwa No.117, what is meant by Dharar is actions that can cause danger or loss to other parties

12 Abd. Shomad, Islamic Law Normalizing Sharia Principles in Indonesian Law (Kencana Prenadamedia Group 2012).[23].

13 Prawitra Thalib, 'Distinction of Characteristics Shariah and Fiqh on Islamic Law' (2018) 33 Yuridika.[439].

${ }^{14}$ Prawitra Thalib, Sharia Concept and Hermeneutic (Lutfansyah Mediatama 2013).[22].

${ }^{15}$ Bank Indonesia, 'Kamus' (2018) < bi.go.id/id/Kamus.aspx?id=S> accessed 29 June 2019.
} 
(ujrah) based on the ijarah principle for the provision of information technologybased infrastructure systems and facilities. The model of information technologybased financing services based on sharia principles that can be carried out by organizers based on the DSN-MUI Fatwa No.117, including:

a. Factoring financing; i.e., financing in the form of accounts receivable collection services based on invoice, whether or not accompanied by a bailout (qardh) given to business actors who have bills to third parties (payor);

b. Financing of Purchase Orders; that is, financing provided to business actors who have obtained orders or work orders for the procurement of goods from third parties;

c. Financing Procurement of goods for business people who sell online (online seller); that is, financing provided to business actors conducting online trading transactions at information technology-based trading service providers (e-commerce platforms/marketplaces) that have established cooperation with Providers;

d. Goods procurement financing for business actors selling online with payments through payment gateway providers, namely financing provided to sellers who are actively selling online through distribution channels managed by themselves and payments made through payment authorization service providers online (payment gateway) that collaborates with the Organizer;

e. Employee Financing, which funding provided to employees who need consumptive financing with a salary-cutting cooperation scheme through an employer institution;

f. Community-based financing (community-based), namely financing provided to community members who need funding, with the payment scheme coordinated through community coordinators/administrators.

In both conventional and sharia fintechs, financiers (financiers) must assume the risk of financing in the event of default, is no state institution or authority responsible for the risk. In addition, funding and financing placed on the organizer's account is not considered as a deposit as a bank guaranteed by the Deposit Insurance Corporation (LPS) so that it becomes a full risk for the financing provider (investor) such as the potential loss of part of or all funding from the financing provider caused by default, fraud / fraud committed by the recipient of financing by deceiving or falsifying personal data and information and work, an economic crisis that could have a negative impact on many aspects resulting in the inability of the recipient of financing to fulfill their obligations and the possibility of the bankruptcy of the provider. 


\section{Characteristics of Ammana, Syariah Funds and Duha Syariah as Organizers of Sharia Fintech}

PT Ammana Fintek Syariah is the first Sharia fintech company registered with OJK with number S-1320/NB.233/2017 on December 22, 2017, to conduct funding activities to MSMEs (Micro, Small and Medium Enterprises) with Sharia principles (P2P - Peer to Shariah Peer Lending) and operates in March 2018. Peer to peer lending (P2PL) is an activity to administer technology-based lending services that must register with OJK. The technology service allows fund owners to fund/ finance business actors in cooperation with other fund owners (Crowdfunding). According to L. Budi Kagramanto ${ }^{16}$ This crowdfunding is included in the Lending based crowdfunding type, which means:

"Lending-based crowdfunding is a fund-raising activity in which people lend money to individuals or companies with reciprocity in the form of interest and refunds upon the expiry of the terms agreed in the agreement. The minimum fund is not restricted but the maximum amount of loan acquisition of one proposer limited according to the regulations of each country. This type of crowdfunding can be a good thing for both parties. This method provides alternative financing for borrowers who are unable to pass the financing qualifications required by a conventional institution such as a bank".

In terms of conducting sharia P2PL activities, Ammana operates using sharia principles, such as having a DPS, by referring to the MUI DSN Fatwa and conducting financing using sharia agreements. Ammana comes via mobile application technology (through Android and Apple applications) that is easy to access and operate. Ammana can jointly fund sharia for the best business people assisted by LKMS (Islamic Micro Cooperative Institution) such as BMT/KSPPS/ BPRS/Sharia Venture Institutions/ other Islamic Financial Institutions which are partners of Ammana. Ammana is supervised directly by the Financial Services Authority (OJK) and the Ministry of Communication and Information, and syariah compliance overseen by the National Sharia Board-Indonesian Ulema Council (DSN MUI) through the presence of DPS assigned and placed to supervise and assist Ammana services to remain within the

${ }^{16}$ L.Budi Kagramanto dan Cita Yustisia Sefiyani, 'The Principle of Contract in Donation Besed Crowdfunding' (2019) 34 Yuridika.[85]. 
compliance corridor in company policy fintech and basic principles of sharia. ${ }^{17}$ In Islamic fintech conducted by Ammana, there are three parties, namely the fund owner/ financing provider (financier), the organizer, namely Ammana and the business actor (the recipient of capital), this can describe below: ${ }^{18}$

Flowchart: Islamic fintech conducted by Ammana

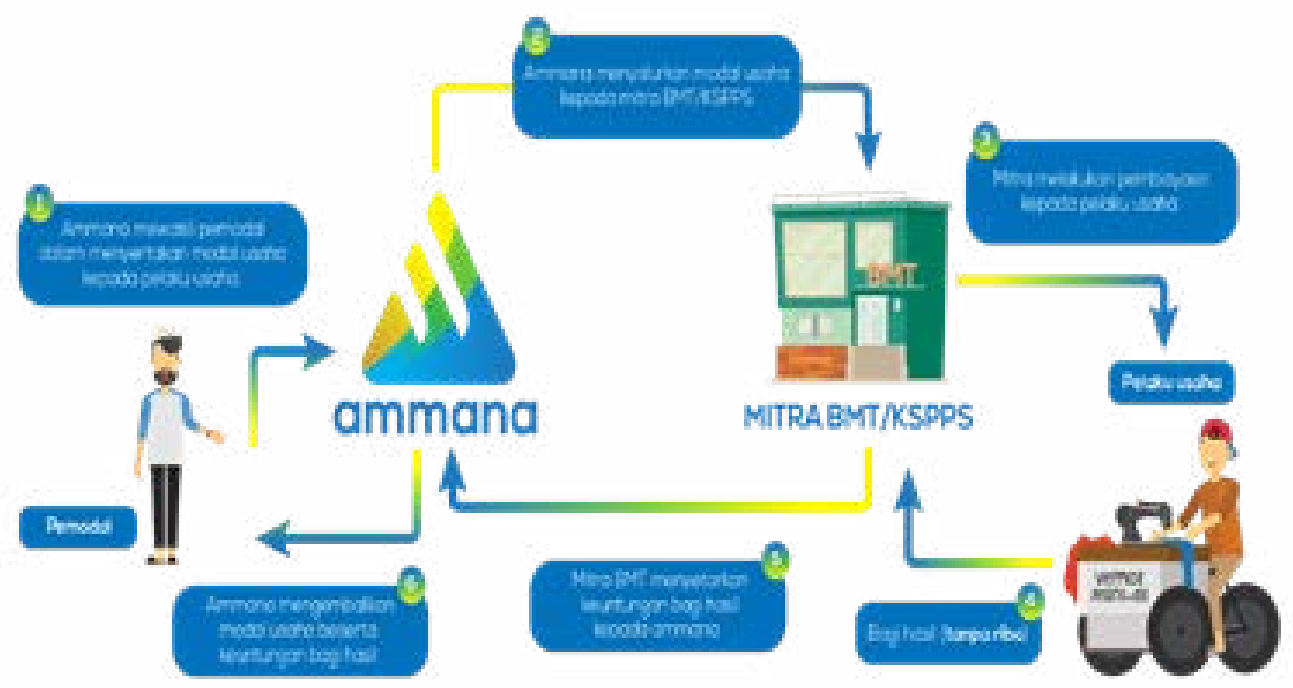

Ammana represents the financiers (financiers) in including business capital to business actors (Micro, Small, and Medium Enterprises/SMEs). The venture capital by Ammana channeled to field partners in this case Sharia Microfinance Institutions/ LKMS (Sharia Cooperative, Baitul Maal wat Tamwil, Rakyar Syariah Financing Bank). Field Partners carry out an assessment, scoring, financing, and business results collection functions. Then by LKMS, the capital is channeled through financing to MSME businesses. The profits obtained by MSME entrepreneurs deposited with LKMS. Then by LKMS, the profit-sharing is deposited in Ammana. Ammana capital return for the financier.

The legal relationship between the grantor (capitalist) and the Ammana framed by the act of wakalah bill ujrah. Which is the kind of agreement that one

17 PT. Ammana Fintek Syariah, 'Tentang Ammana' (PT. Ammana Fintek Syariah, 2018) $<$ https://ammana.id/profile $>$ accessed 27 May 2019.

${ }_{18}$ PT. Ammana Fintek Syariah, 'Apa Saja Jenis Pendanaan Yang Tersedia Di Ammana?' (PT. Ammana Fintek Syariah, 2018) <https://ammana.id/help/faq/apa-saja-jenis-pendanaan-yang-tersedia-di-ammana> accessed 28 May 2019. 
party, in this case, the grantor (grantor/muwakkil) empowers the other party, in this case, Ammana to take the necessary action for and In the name of the grantor and in that behalf, the Ammana (the beneficiary/representative) shall receive the award or wages? The wakalah is a tabarru 'type of ta'un, which is to help based on goodness and piety as explained in Fatwa DSN No. 10 / DSN-MUI / IV / 2000 on Wakalah.

In the legal relationship between the financing provider and the recipient of the financing, there are 2 (two) contracts that frame it, namely the musyarakah contract and the mudharabah agreement.

a. Musharaka contract. The parties to the musyarakah contract are financiers (financiers) in this case represented by Ammana with LKMS (recipients of financing), each of which contributes capital. LKMS then distributes the capital to business actors (MSMEs). LKMS that interact directly in the field professionally with business actors (UMKM), because LKMS has already accustomed to operating financial and financing management. Thus it can reduce the risk to the financing provider (investor) in making funding.

b. Mudharabah contract. The parties in the mudharabah contract are financing providers (investors) in this case represented by Ammana with LKMS, but in this case, the capital is $100 \%$ from the financing provider (investor). The capital then channeled according to the needs of LKMS and agreement between LKMS and MSME business actors.

The characteristics of the musyarakah and mudharabah contracts are as follows:

Tabel 1. Characteristics of Mudharabah and Musyarakah Contracts

\begin{tabular}{lll}
\hline \multicolumn{1}{c}{ Content } & \multicolumn{1}{c}{ Mudharabah } & \multicolumn{1}{c}{ Musyarakah } \\
\hline $\begin{array}{l}\text { Underlying } \\
\text { principle }\end{array}$ & $\begin{array}{l}\text { The financing based on the principle of } \\
\text { profit-sharing (profit and loss sharing } \\
\text { principle) }\end{array}$ & $\begin{array}{l}\text { The financing based on the } \\
\text { principle of profit-sharing (profit } \\
\text { and loss sharing principle) }\end{array}$ \\
Type of Capital & Type of capital in the form of cash. & $\begin{array}{l}\text { The type of capital can be in the } \\
\text { form of money and property that } \\
\text { valued in money. }\end{array}$ \\
& $\begin{array}{l}\text { In mudharabah financing, only the } \\
\text { capital owner (shahibul maal) lends } \\
\text { his capital to the capital manager } \\
\text { (mudharib). With such capital, the } \\
\text { manager (mudharib) will undertake }\end{array}$ & \\
& $\begin{array}{l}\text { Ectivities to manage the capital. } \\
\text { the business carried out together. }\end{array}$
\end{tabular}




$\begin{array}{ll}\text { Advantage } & \begin{array}{l}\text { These benefits divided by agreement } \\ \text { (profit sharing ratio) }\end{array} \\ & \begin{array}{l}\text { If you get a profit, then the } \\ \text { distribution of profits is based on } \\ \text { a percentage agreed upon }\end{array} \\ & \text { In the event of a loss it will be borne } \\ \text { maal) with the record of the loss not } \\ \text { due to the will of the capital manager } \\ \text { (mudharib), but the capital manager If a loss occurs, it is borne together } \\ \text { for the loss of time, energy and mind. } \\ \text { Loss capital. } \\ \text { While the loss is due to the negligence } \\ \text { of the capital manager (mudharib), } \\ \text { then the capital manager must bear the } \\ \text { loss. }\end{array}$

While the contracts that frame the legal relationship between LKMS and MSME business actors generally include musyarakah, mudharabah, ijarah, salam, istishna, and murabahah contracts).

The success rate of the organizer in facilitating the settlement of financing obligations between the financing recipient and the financier within a period of up to 90 days from maturity (success rate of 90 or TKB90) must publish in the framework of transparency principle following Article 29 letter a POJK77 / 2016. The formula used to determine TKB90 is as follows: ${ }^{19}$

$$
\text { TKB90 }=100 \%-\text { NPL90 }
$$

NPL90 determined using the calculation formula:

NPL90 $=\frac{\text { Outstanding financing over } 90 \text { days }}{\text { Overall Outstanding }} \times 100 \%$

The higher the percentage of TKB90 held by the Operator, the better the Operator will run an Information Technology-Based Financing Service. The return success rate (TKB90) in Ammana is $99.23 \% .^{20}$

Ammana not only provides funding and financing services but also provides an opportunity for funders to make endowments and donations. For example, the waqf fishing boat program that was hit by the Sunda Strait tsunami on December 22, 2018. So Ammana in collaboration with ACT - Global Wakaf invites lenders to

\footnotetext{
19 PT. Ammana Fintek Syariah (n 15).

${ }^{20}$ ibid.
} 
represent the provision of new boats/boats for fishers. ${ }^{21}$ Waqf is a tool of Islamic philanthropy since the beginning of the arrival of Islam. Waqf has proven to be an instrument of social security, not only to help basic needs but also to play a part in more productive empowerment in all sectors such as education, social, economic, and cultural. In addition to immovable assets from waqf, there are also more productive cash waqfs used. A very potential but unpopular cash waqf has caused the role of waqf not to be optimal as an instrument of community welfare. Indonesia, with the largest number of Muslims in the world, should be the basis for optimizing waqf. ${ }^{22}$

The financing channeled by Ammana does not require special guarantees, namely material guarantees or individual guarantees. However, in terms of Ammana financing, efforts have been made to minimize the risk of financing, namely failure to pay by cooperating with LKMS/Nazhir, ${ }^{23}$ so the risk is sharing. Before conducting the collaboration, Ammana conducted socialization and visit and analysis for the selection of the LKMS/Nazhir. After an analysis of LKMS/Nazhir and Ammana, a cooperation agreement signed. LKMS/Nazhir open a virtual account. LKMS/ Nazhir assisted with initial guidance and assistance for MSME/productive/social businesses. Before LKMS/Nazhir distributed funding, a selection, analysis, and evaluation/scoring of prospective prospects of MSME /productive/social business actors conducted. Then LKMS/Nazhir proposed UMKM/productive/social business actors elected to Ammana to appear on Ammana apps. LKMS/Nazhir prepare a contract with MSME/Productive/Social Business that is already fully funded. LKMS/Nazhir prepared a liquidation of funds from the Ammana Funding Partner. After the funds disbursed, LKMS/Nazhir provides guidance and assistance to MSME/productive/social businesses. Besides, LKMS/Nazhir also assists with

\footnotetext{
21 ibid.

${ }^{22}$ Muhammad Nafik Hadi Ryandono, 'Fintech Waqaf: Solusi Permodal Perusahaan Strartup Wirausaha Muda' (2018) 7 Studi Pemudi.[115].

${ }^{23}$ In Law Number 41 of 2004 concerning Endowments it is explained that Nazhir is a party that receives endowments from Wakif to be managed and developed in accordance with their designation. There are two waqf, namely individual nadzir and nadzir with legal status
} 
the repayment/settlement program for MSME entrepreneurs/productive/social enterprises. ${ }^{24}$ PT. Indonesian Sharia Funds registered with the OJK on June 8, 2018 under Number S-384/NB.213/2018. In contrast to Ammana which focuses on MSMEs, while the Sharia Fund funding offered is devoted to:

a. Funding for the construction of property units sold at an agreed price between the Sharia Fund and Sharia Developer partners.

b. Funding ownership of shared property, with the aim of leasing then sold after a certain period. The benefit is the rental revenue and the increase in property prices when the ownership portion sold.

The funding provider or recipient of financing to become a member of the Sharia Fund must register first. In the Sharia Fund there are 2 (two) agreements, namely:

1. Agreement between the financier and the Sharia Fund as an arrangement framed by the "Technology-Based Financing Service Agreement with Sharia Principles".

2. Agreement between the Sharia Fund and the recipient of financing framed by the "Murabahah Financing Agreement".

The "Technology-Based Financing Services Agreement With Sharia Principles" between PT. Dana Syariah Indonesia and the financing providers contains provisions that PT. Dana Syariah Indonesia appointed as the representative of the financiers in managing electronic system services that bring together the financiers with the recipients of financing covering services (preparing, collecting, managing, analyzing, storing, displaying, announcing, sending, and distributing electronic information in financial services). Based on the clause of the agreement, the agreement is a contract for ujrah bill because of PT. The Indonesian Sharia Fund as a representative/proxy who acts for and on behalf of the authorization/muwakkil, namely the lender and for the work, PT. Indonesian Syariah Funds get ujrah. The agreement contains the following clause:

1. With the approval of the financier, the organizer (PT. Dana Syariah Indonesia) will place the funds channeling funds to the recipients of the financing.

${ }^{24}$ PT. Ammana Fintek Syariah (n 15). 
2. Based on the intention and desire of the financier to place his funds in this financing facility, the financier grants power and authority to the organizer (PT. Dana Syariah Indonesia) to channel the financing facility to the recipient of the financing.

Based on the clause above shows that PT Dana Syariah Indonesia as the representative/power of attorney from the financier. It is different from the provisions of POJK 77/2016 which states that there are 2 (two) agreements, namely the agreement between the lender and the organizer and the agreement between the lender and the loan recipient. However, in Ammana and at PT. The Indonesian Sharia Fund, it is not between the direct financing provider and the recipient of the financing, but it is between Ammana or PT. Dana Syariah Indonesia as the organizer and the recipient of the financing. Ammana and PT. The Indonesian Sharia Fund as a representative/power acting for and on behalf of the financier (financier).

In the "Murabahah Financing Agreement". PT. The Indonesian Sharia Fund in this case acts for and on behalf of the financier to become a party to the "Murabahah Financing Agreement". "Murabahah Financing Agreement" contains clauses, among others:

1. Principal provisions of the contract containing the purchase price, profit margins, selling price, administrative costs, type of financing, financing period, financing maturity, installments per month, maturity, type of guarantee, proof of ownership of the guarantee and the name of the owner of the guarantee;

2. When there is a late payment by the recipient of the financing, there is a late fee and the fine allocated by the organizer (PT.Dana Syariah Indonesia) for social funds;

3. The organizer (PT.Dana Syariah Indonesia) can request an advance (urbun) from the recipient of financing for the purchase of goods. The advance payment would become part of the payment of the loan recipient if the Murabahah Funding implemented;

4. Notwithstanding the installment payment, the recipient of the financing can make the Accelerated Repayment of all remaining outstanding obligations which made before the expiration of the Financing due.

In the "Murabahah Financing Agreement" PT. Dana Syariah Indonesia requires a material guarantee; in this case, the items financed by the murabahah financing. For example, funding the construction of a property unit, proof of ownership of the property as a guarantee object. If the collateral object is in the form of land rights with ownership of ownership rights or building usufructuary rights, the collateral institution that charges it is the mortgage. Therefore, the parties to the principal 
agreement, namely "Murabahah Financing Agreement" are between PT. Dana Syariah Indonesia and recipients of financing, in the agreement on liability as an accessory agreement, is between PT. Dana Syariah Indonesia as the party holding mortgage rights and the recipient of financing as the party giving the mortgage rights. The clause in the "Murabahah Financing Agreement" contains the following: 1. In order to guarantee repayment of Murabahah debt, the recipient of the financing must submit Goods financed as collateral, as well as submit proof of the original and legal guarantee of ownership to be bound following the provisions of the applicable legislation;

2. Recipients of financing are required to provide full assistance to enable the Organizer (PT. Dana Syariah Indonesia) to bind the Goods financed with the Financing facility as collateral according to the method and at the time considered good by the Operator (PT.Dana Syariah Indonesia), Proof of Goods Ownership and The binding of the Guaranteed Goods is controlled by the Operator (PT. Dana Syariah Indonesia) until the entire amount of Financing is repaid;

3. All costs associated with binding Guaranteed Goods borne by the recipient of the financing.

If the recipient of the financing broken the promise, then the person entitled to carry out warnings and actions to the recipient of the financing is PT. Dana Syariah Indonesia. Likewise, the authority to execute the object of mortgage is in PT. Dana Syariah Indonesia, not in the financier, because of PT. Dana Syariah Indonesia is the holder of the mortgage stated in the Mortgage Certificate. It is also confirming in the clause in the "Murabahah Financing Agreement":

1. If the recipient of the financing is in default, then after warning the financing recipient, the Organizer (PT.Dana Syariah Indonesia) has the right to take the following actions:

a. Execute collateral items based on the prevailing laws and regulations;

b. Carry out sales of collateral based on Power of Attorney for Selling made by the recipient of the financing;

c. Establish sales prices at prices considered good by the Operator (PT.Dana 
Syariah Indonesia);

2. If the recipient of the financing because he is no longer able to meet his obligations to pay installments to repay Financing, and on that basis the recipient of the financing surrenders the goods used as collateral Financing to the Operator (PT.Dana Syariah Indonesia) has the right to carry out these actions in paragraph 1 of this article .

Fintech syariah which just registered on April 30, 2019, is PT. Duha Madani Syariah is registered with OJK with number S-292/NB.213/2019. Duha Syariah does not provide financing in the form of cash but consumptive financing, namely the purchase of goods or services and financing of Umrah trips and halal tourism. It stated that PT Duha Madani Syariah was the organizer that brought together or connected between the Financing Provider and the Financing Receiver based on Sharia principles through an electronic system (platform). However, in Duha Sharia, there are no services for financiers only for the recipients of financing, so it is not possible for the financiers to contribute to the financing offered by Duha Sharia. In contrast to Fintech Sharia in Ammana and Sharia Funds which provide an opportunity for financiers to contribute to providing financing to financing recipients even though in Duha Sharia it is stated that there is a wakalah agreement bill ujrah is a cooperation in granting power to channel funds directly from the Financing Provider (Fund owner) to the Recipient Funding through the Duha Syariah platform. In addition, the definition given by Duha Syariah that the wakalah bil Ujrah contract is a cooperation agreement is not appropriate because the wakalah contract bil ujrah according to Fatwa DSN Number 52/DSN-MUI/III/2006 concerning Wakalah Agreement bil Ujrah on Syariah Insurance and Sharia Reinsurance is a contract of authorization from participants to insurance companies to manage participant funds in exchange for giving ujrah (fee). The contract that frames the parties' legal relationship in financing is:

a. Murabahah agreement, namely the sale and purchase agreement between PT. Duha Madani Syariah with the recipient of financing in the purchase of halal products sold in e-commerce or marketplaces in collaboration with duha syariah. The payment is by installments starting from 3 months to a maximum of 12 months. The maximum limit for purchasing goods or services is Rp. 20,000,000,- 
b. Akad Ijarah, the contract between PT. Duha Madani Syariah with the recipients of funding in religious travel financing in the form of Umrah and halal tours sold in e-commerce or marketplace in collaboration with Duha Syariah. The payment is by installments starting 12 months to a maximum of 24 months. The maximum limit for purchasing goods or services is Rp. 30,000,000,-

Margin amount for Consumer financing (Purchase of goods/services) $=$ Flat $2.0 \%$ per month while the Ujroh for financing Umrah Travel \& Halal Tourism $=$ Flat $1.5 \%$ per month. On financing, there are no registration fees, administrative fees, late payment penalties, and accelerated payment fees. The financing offered by Duha Syariah does not require special guarantees, namely material guarantees or individual guarantees so that the legal relationship is only guaranteed by general guarantees as stipulated in Article $1131 \mathrm{BW}$. Then the position of Duha Syariah is only as a concurrent creditor whose position is equal to that of other concurrent positions, so that is not prioritized in terms of payment of financing. Therefore, to minimize the risk of financing Duha Sharia such as default, Duha Sharia conducts the principle of prudence by conducting a very strict feasibility analysis at the time of filing financing. However, if the company/institution of the prospective beneficiary has cooperated with Duha Syariah, it will be easier for Duha Syariah because the payment is using the salary deduction scheme of the beneficiary.

\section{Conclusion}

The distribution about Sharia fintech is still referring to DSN-MUI Fatwa Number 117/DSN-MUI/II/2018 concerning Information Technology-Based Financing Services Based on Sharia Principles because OJK has not yet regulated Sharia fintech. The Financial Services Authority Regulation Number 77/ POJK.01/2016 Concerning Information Technology-Based Lending and Borrowing Services regulates conventional fintech as evidenced by regulating interest rates. When disbursing financing to the recipient of financing, Ammana, Sharia Funds and Sharia Duha act as representatives/powers of the financiers (financiers) so that Ammana, Sharia Funds and Shariah Duha will get a ujrah from these activities. The 
contract that frames the legal relations of the parties, among others, is akad wakalah bil ujrah, mudharabah, musyarakah, ijarah dan murabahah.

\section{Bibliography}

Abd. Shomad, Islamic Law Normalizing Sharia Principles in Indonesian Law (Kencana Prenadamedia Group 2012).

Bank Indonesia, 'Kamus' (2018) < bi.go.id/id/Kamus.aspx?id=S> accessed 29 June 2019.

Khotibul Umam, 'Pelarangan Riba Dan Penerapan Prinsip Syariah Dalam Sistem Hukum Perbankan Di Indonesia’ (2017) 27 Mimbar Hukum.

L.Budi Kagramanto dan Cita Yustisia Sefiyani, 'The Principle of Contract in Donation Besed Crowdfunding' (2019) 34 Yuridika.

Muhammad Nafik Hadi Ryandono, 'Fintech Waqaf: Solusi Permodal Perusahaan Strartup Wirausaha Muda' (2018) 7 Studi Pemudi.

Otoritas Jasa Keuangan, 'Penyelenggara Fintech Terdaftar Dan Berizin Di OJK per 31 Mei 2019' (Otoritas Jasa Keuangan, 2019) <https://ojk.go.id/id/beritadan-kegiatan/publikasi/Pages/Penyelenggara-Fintech-Terdaftar-dan-Berizindi-OJK-per-31-Mei-2019.aspx > accessed 27 May 2019.

Prawitra Thalib, 'Application of Qowaid Fiqhiyyah in Islamic Contemporary Law' (2016) 31 Yuridika.

Prawitra Thalib, 'Distinction of Characteristics Shariah and Fiqh on Islamic Law' (2018) 33 Yuridika.

Prawitra Thalib, Sharia Concept and Hermeneutic (Lutfansyah Mediatama 2013).

PT. Ammana Fintek Syariah, 'Apa Saja Jenis Pendanaan Yang Tersedia Di Ammana?' (PT. Ammana Fintek Syariah, 2018) <https://ammana.id/help/faq/ apa-saja-jenis-pendanaan-yang-tersedia-di-ammana $>$ accessed 28 May 2019.

—_, 'Tentang Ammana' (PT. Ammana Fintek Syariah, 2018) <https://ammana.id/ profile $>$ accessed 27 May 2019.

Trisadini Prasastinah Usanti and Fiska Silvia, 'Legal Protection of The Contracting Parties in The to Peer Lending Based on Financial Technology (P2P Lending Fintech) in Indonesia' (2018) 131 Advance in Social Science, Education and Humanities Research (SSEHR).

HOW TO CITE: Trisadini Prasastinah Usanti, Prawitra Thalib and Nur Utari Setiawati, 'Sharia Principles on Information Technology-Based Financing Services' (2020) 35 Yuridika. 